\title{
UTOPIA KHILĀFAH ISLĀMIYYAH: Studi Tafsir Politik Mohammed Arkoun
}

\author{
Muhammad Rikza Muqtada \\ Istitut Agama Islam Negeri Salatiga \\ e-mail: mrmcandi@gmail.com
}

\begin{abstract}
This paper aims to study Muhammed Arkoun's political interpretation thought about the ideal state. He shows that each political contestation often uses religion as a legitimation of political interest. Many of discourses in Qur'an, such as old narratives of Qur'an (amtsal al-Qur'an), is often presented to modify the existing political conditions. Moreover, some of the terms of Quranic discourse, like as 'Muslim' or 'Kafir' (infidel), is always in a binary position to create sharp differences between the militant and the opposition. The Qur'anic discourses, intentionally or not, since the time of revealing of the Qur'an has been dragged into the political territory as well the theological territory, so it is able to change the profane history into the sacred story with the great power of sacralization. Although the Qur'an is within the dialectic area, some of Islamist always reduces the meaning of Qur'an to support their agenda in realizing the Islamic State (Khilafah Islamiyah). For Arkoun, that desire is a utopian politics idea and nothing more than an interpretation of religious texts. There is no agreement among the people about the ideal state concept. Therefore, Arkoun offers the concept of ideal state is if religious authorities and political authorities apply their function professionally yet integrated.
\end{abstract}

\begin{abstract}
Abstrak: Tulisan ini menggagas pemikiran tafsir politik Muhammed Arkoun tentang negara ideal. M. Arkoun menggambarkan bahwa dalam setiap kontestasi politik sering menyeret agama sebagai legitimasi pemangku kepentingan. Wacana-wacana dalam al-Qur'an seperti teladan-teladan kuno (amthāl alQur'an) sering dihadirkan untuk memodifikasi kondisi politik yang ada. Selain itu, beberapa istilah dalam wacana al-Qur'an, seperti 'Muslim' dan 'kafir', diposisikan biner untuk menciptakan perbedaan tajam antara kelompok militan dan oposan. Wacana-wacana qur'ani tersebut, dengan sengaja atau tidak, sejak masa turunnya ayat telah diseret masuk ke dalam wilayah politik sekaligus wilayah teologis, sehingga mampu mengubah sejarah yang profan menjadi kisah sakral dengan kekuasaan sakralisasi yang besar. Meskipun al-Qur'an berada dalam ruang dialektis yang bebas, oleh sebagian kelompok Islamis pemaknaan alQur'an direduksi dan dibawa untuk mendukung agenda mewujudkan Islamic State (negara Islam). Bagi Arkoun, keinginan tersebut merupakan gagasan politik yang utopis dan tak lebih dari sebuah interpretasi atas teks agama. Tidak ada kesepakatan di kalangan umat mengenai konsep negara ideal. Karena itu, Arkoun menawarkan konsep negara ideal adalah jika otoritas keagamaan dan otoritas politik berlaku sesuai dengan fungsinya namun tetap terintegrasi.
\end{abstract}

Keywords: al-Qur'an; politisasi tafsir; khilāfah Islämiyah 


\section{A. Pendahuluan}

Pertama kali saya ajukan fenomena penolakan Syi'ah melalui spandukspanduk provokatif di sejumlah tempat di Indonesia. Di Sentul Bogor pada 11 Februari 2015 sempat menimbulkan konflik yang dipicu pemasangan spanduk penolakan Syi'ah yang tertempel di pagar masjid az-Zikra pimpinan Muhammad Arifin Ilham. Entah mengapa kasus tersebut justru mengalami divusi ke berbagai tempat. Di beberapa titik strategis Daerah Istimewa Yogyakarta (DIY), misalnya, juga tertempel spanduk provokatif penolakan Syi'ah. Sebenarnya provokasi yang sangat rentan menimbulkan konflik ini tidak murni muncul di Indonesia, melainkan isu impor transnasional dari dari Timur Tengah, yakni konflik politik bebuyutan antara Syi'ah versus Wahabi yang dikemas menggunakan agama.

Dalam kasus lain seperti pencalonan Ahok menjadi gubernur DKI Jakarta 2017 pun mendapat kecaman keras dari Islam radikal. Pelbagai langkah telah dilakukan, mulai dari aksi 411, aksi 212, hingga aksi 112, untuk membendung kekuatan politik Ahok. Tidak habis pikir pada putaran kedua mereka mengeluarkan ancaman teologis dengan cara memasang spanduk provokatif pada dinding-dinding masjid di wilayah Jakarta terkait penolakan shalat jenazah bagi pendukung Ahok-Jarot. Persoalan-persoalan semacam ini sebenarnya muncul dari penafsiran-penafsiran sempit mengenai sumber Islam, khususnya QS. alMaidah: 51. Konsekuensinya, Islam sebagai wadah dijadikan sebagai kendaraan politik untuk menjajah negara yang mayoritas penduduknya sudah Islam. Proyek utama mereka adalah mengganti ideologi pancasila yang mengedepankan multikultural menjadi negara Khilafah yang dinilai lebih Islami.

Isu merubah ideologi NKRI dari Pancasila menjadi Khilafah Islämiyah akan selalu dikampanyekan oleh para Islamis, mungkin hingga kepentingan mereka terwujud. Islamis telah membingkai Islam dalam batasan-batasan ideologis, tafsir harfiah, dan platform politik mereka sehingga tidak mampu melihat, apalagi memahami, kebenaran yang berseberangan dengan mereka. Dengan keterbatasan inilah, mereka mudah menuduh kelompok lain yang berebeda atau tidak mendukung agenda mereka dengan tuduhan "Kafir/Murtad" sebagai oposan dari Mukmin/Muslim. Dengan menciptakan kategorisasi biner, Mukmin/Muslim versus Kafir/Murtad, militan garis keras mampu mengelabui umat Islam awam untuk memuluskan misinya, serta membayang-bayangi 
mereka dengan ancaman dogmatis. Inilah yang disebut Mohammed Arkoun ${ }^{1}$ sebagai sublimasi keagamaan dari suatu ketegangan sosio-politik antara mereka yang ta'at serta tunduk pada kekuasaan baru dan mereka yang menentangnya. Suatu pertaruhan politik langsung yang ditonjolkan melalui janji kehidupan abadi atau ancaman siksaan abadi. $^{2}$

Arkoun mengakui bahwa dalam al-Qur'an memang menyebutkan istilahistilah Mukmin, Muslim, Kafir, Murtad beserta turunan-turunannya, tetapi istilah-istilah tersebut bukan berarti diposisikan secara biner. Sayangnya para Islamis sering membawa kata-kata tersebut ke dalam tafsir politik. Konsekuensi logisnya adalah berubahnya Islam dari agama menjadi ideologi politik. Nilai-nilai luhur Islam dalam al-Qur'an direduksi menjadi Islam ideologis yang sempit dan kaku. Klaim-klaim ekslusif yang dilontarakan para Islamis sering mengarah pada keotoritasan mereka sebagai wakil Allah di bumi, dan membawa keyakinan bahwa pemahaman mereka atas wahyu Tuhan adalah kebenaran absolut. Sikap ini justru membekukan kedinamisan tafsir yang harusnya tetap berada dalam ruang wacana terbuka. Mereka benar bahwa kekuasaan milik Allah (lā ḥukma illā lillāh), tetapi tidak seorang pun yang sepenuhnya memahami kekuasaan-Nya sebagaimana sabda Nabi "kalian tidak tahu apa sebenarnya hukum Allah". 3 Dengan kata lain, asumsi dasar mereka sebatas ijtihādi.

Dengan mengabaikan prinsip ijtihādi ini, pejuang Khilafah Islāmiyah menjadikan Islam sebagai senjata ampuh dalam berpolitik untuk mendiskreditkan dan menyerang siapa pun dari kelompok mana pun yang memiliki cara pandang politik berbeda dengan mereka. Dengan dalih memperjuangkan

\footnotetext{
1Muhammad Arkoun (lahir tanggal 28 Februari1928) adalah seorang filsuf Islam Modern asal Algeria (Aljazair). Karir akademiknya ditempuh di Universitas Aljazair (1950-1954), Universitas Sorbonne (1956), dan menjadi pengajar di Universitas Vincennes (Paris VIII). Latar belakang kehidupannya kaya akan tradisi dan bahasa yang berlainan menjadi faktor penting dalam membentuk cara berfikirnya. Persentuhannya dengan beberapa kajian mutakhir melalui karya beberapa ilmuan, filosof, antropolog dan teolog Barat memberikan landasan yang kuat bagi Arkoun dalam mencetuskan proyek pemikiran Islam yang berupa kritik epistemologi nalar Islam yang berlanjut dengan pembongkaran terhadap hegemoni ortodoksi Islam sebagai langkah awal (Dekonstruksi) dan membangun kembali rangkaian pemahaman tentang pemikiran Islam sebagai langkah kedua (Rekonstruksi). M. Arkoun, Tārikhiyah al-Fikr al-'Arabiy al-Islāmiy, terj. Hasyim Shalih, (Beirut: Markaz al-Inma' al-Qoumi, 1986), h. 73-74.

${ }^{2}$ Mohammed Arkoun, Kajian Kontemporer al-Qur'an, diterjemahkan dari buku Lectures du Coran, terj. Hidayatullah, (Bandung: Pustaka, 1998), h. 227.

${ }^{3}$ Khaled Abou El-Fadl, Atas Nama Tuhan: Dari Fikih Otoriter ke Fikih Otoritatif, diterjemahkan dari Speaking in God's Name: Islamic Law, Authority and Women, (Jakarta: Serambi, 2003), h. 48.
} 
dan membela Islam, mereka sebenarnya memperjuangkan suatu agenda politik tertentu yang dikemas dengan balutan agama, sehingga siapa pun yang melawan mereka dianggap melawan agama. Mereka berusaha keras menolak budaya dan tradisi yang selama ini menjadi bagian integral kehidupan bangsa Indonesia yang sangat ramah dan mengahargai perbedaan, kemudian menggantinya dengan budaya dan tradisi impor dari Timur Tengah, terutama kebiasaan Wahabi-Ikhwanul Muslimun yang berkarakter keras dan tidak mengenal kompromi, ${ }^{4}$ untuk kemudian menyeragamkan bentuk-bentuk tradisi, ideologi, maupun negara sesuai dengan kehendak mereka. Singkatnya, agama adalah negara.

\section{B. Tafsir dan Takwil Perspektif Mohammed Arkoun}

Dalam kajian Islam, hampir mayoritas ulama' sepakat bahwa Islam didasarkan pada kitab wahyu yang disebut al-Qur'an. Setidaknya di sini ada dua hal yang perlu dipahami terlebih dulu, yaitu apa itu wahyu dan apa itu al-Qur'an?. Berangkat dari kerangka ini lah Islam bisa digambarkan lebih utuh. Islam sebagai sistem nilai universal yang dijadikan pedoman hidup manusia sebagai mandataris Tuhan di bumi.

Wahyu dalam konsepsi Islam disebut dengan tanzīl (turun), sebuah metafora fundamental karena umat manusia yang berpandangan vertikal diundang untuk menuju Tuhan, transendensi. Wahyu dalam pengertian ini bersifat luas dan abadi yang kebenarannya di luar jangkauan manusia. Untuk menunjuk realitas wahyu seperti ini, biasanya dipakai anggitan al-Lauh al-Mahfüz (Preserved Tablet) atau Umm al-Kitāb. Di sana lah kesakralan wahyu berada. Karena wahyu bersifat transenden, sedangkan ia untuk manusia yang kemampuannya terbatas, maka wahyu kemudian diturunkan dalam bentuk pengujaran lisan melintasi realitas sejarah yang disebut sebagai religious discourse dan berfragmen dalam bentuk kitab Taurat, Zabur, Injil dan al-Qur'an. Inilah wahyu yang bisa diakses oleh manusia, oleh Arkoun diistilahkan dengan "wahyu edisi dunia" (editions terrestres). ${ }^{5}$ Singkatnya, wahyu-wahyu yang disampaikan kepada manusia dengan perantaraan para rasul hanyalah penggalan dari Kalam

\footnotetext{
${ }^{4}$ Abdurrahman Wahid (ed), Ilusi Negara Islam: Ekspansi Gerakan Islam Transnasional di Indonesia, (Jakarta: The Wahid Institute, 2009), h. 19.

${ }^{5}$ http://www.filsafatpemikiranmuhammadarkoun.com
} 
Allah yang tak terbatas, kemudian dimanifestasikan ke dalam bahasa manusia yang secara linguistik telah diartikulasikan dalam bahasa Ibrani (Alkitab), bahasa Aramaik (Bible) dan bahasa Arab (al-Qur'an). ${ }^{6}$

Wahyu qur'ani hanyalah bahasa manusia yang memparodikan wahyu sejati, sehingga masih membutuhkan penjelasan mengapa suatu parodi terhadap wahyu bisa menghasilkan berbagai dampak psikologis, budaya dan sejarah. Arkoun memandang wahyu berupa al-Quran ini telah mengalami modifikasi, revisi dan subsitusi. ${ }^{7}$ Asumsi ini tercermin dalam al-Muṣhāf al-Uthmānī yang dikodifikasi pada masa kepemimpinan Utsman bin Affan, dan masih dipakai oleh mayoritas Muslim sampai hari ini. ${ }^{8}$ Oleh karena itu, Arkoun menyebut almușhāf ini sebagai Closed Official Corpus (kanon resmi tertutup) atau mușhāf standar yang sudah ditentukan secara resmi dan final. ${ }^{9}$

Al-Qur'an edisi dunia ini merupakan sekumpulan entitas simbolik yang sarat dengan makna. Oleh karena itu, al-Qur'an diposisikan sebagai penyedia wacana makna, yakni teks yang terbuka atas segala makna atau teks bagi seluruh umat manusia. ${ }^{10}$ Dalam mengangkat makna al-Qur'an, Arkoun berusaha menjauhi pretensi untuk menetapkan "makna sebenarnya dari al-Qur'an". Suatu tindakan konyol apabila menutup pemaknaan teks al-Qur'an, kemudian menganggapnya sebagai kebenaran absolut. al-Qur'an dibiarkan sebagai Corpus yang terbuka terhadap segala bentuk interpretatif. al-Qur'an bisa mengangkat takwil sekaligus menerima takwil, dan -mungkin- hanya bisa dipahami dengan takwil. Banyak generasi penafsir telah terperangkap dalam ilusi tersebut. Untuk itu, pembakuan makna secara definitif yang dilakukan oleh pemikiran spekulatif

\footnotetext{
${ }^{6}$ Mohammed Arkoun, Rethinking Islam, terj. Yudian W. Asmin, (Yogyakarta: Pustaka Pelajar, 1996), h. 48-49.

${ }^{7}$ Abdul Kadir Hussain Salihu, Hermeneutika al-Qur'an menurut Muhammad Arkoun: Sebuah Kritik, dalam ISLAMIA: Majalah Pemikiran Dan Peradaban Islam, Thn I No 2, Juni-Agustus 2004, hal: 21.

${ }^{8}$ Sebagai jawaban kegelisahan atas banyaknya sahabat penghafal al-Qur'an yang gugur dalam perang Yamamah, dan juga menghindari konflik politis atau perdebatan di kalangan umat Islam dengan menyeragamkan dan membakukan corpus Alqur'an. M. Arkoun, Rethinking Islam..., h. 55

${ }^{9}$ Status korpus resmi yang tertutup menurut prosedur-prosedur yang dikembangkan dan dibimbing oleh sarjana-sarjana: resmi karena teks-teks ini sebagai akibat dari seperangkat keputusan yang diambil oleh "otoritas-otoritas" yang diakui oleh komunitas; tertutup karena tidak seorang pun diperkenankan untuk menambah atau mengurangi kata-kata, memodifikasi suatu bacaan dalam Corpus yang sekarang dinyatakan otentik. M. Arkoun, Rethinking Islam..., h. 50.

${ }^{10}$ M. Arkoun, Tãrikhiyah al-Fikr..., h. 145.
} 
perlu didemistifikasi. ${ }^{11}$ Dalam arti tidak ada penafsiran al-Qur'an yang mencapai titik final (absolut). Tidak mungkin sebuah pembacaan interpretatif menutupi isi al-Qur'an yang begitu luas, karna salah satu keistimewaan al-Qur'an adalah memiliki beragam makna.

Intinya Arkoun membedakan al-Qur'an edisi dunia dalam dua periode. Pertama, periode diskursus kenabian (Prophetic Discourse), di mana al-Qur'an lebih suci, lebih autentik, dan lebih dapat dipercaya dibanding ketika dalam bentuk tertulis. Sebabnya, al-Qur'an terbuka untuk semua arti ketika dalam bentuk lisan, tidak seperti dalam bentuk tulisan. Kedua, Arkoun berpendapat status al-Qur'an dalam bentuk tulisan telah berkurang dari kitab yang diwahyukan menjadi sebuah buku biasa. Arkoun berpendapat bahwa mușhăf itu tidak layak untuk mendapatkan status kesucian. Tetapi Muslim ortodoks meninggikan korpus ini ke dalam sebuah status sebagai firman Tuhan.

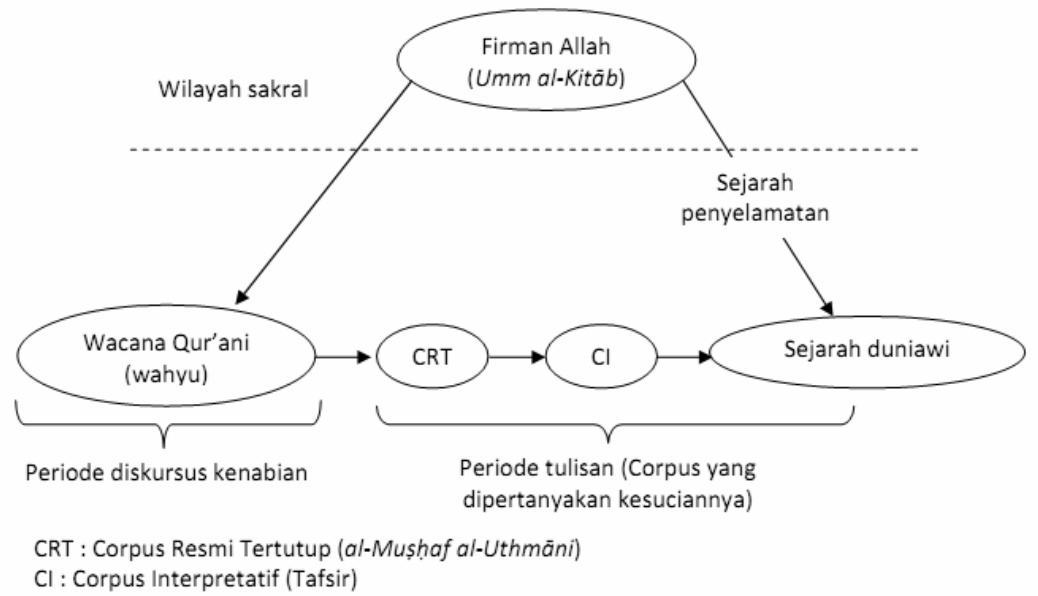

Skema di atas Arkoun menggambarkan potret gerakan yang oleh Allah dijadikan sarana untuk mewahyukan sebagian kitab dari langit kepada umat manusia melalui simbolik dan jalur vertikal turunnya wahyu dan kembali naik menuju transendensi. Pada jalur horisontal, jalur sejarah duniawi, operasioperasi manusiawi berangkat dari wacana Qur'ani (pengucapan-pengucapan lisan oleh Nabi pada saat-saat wahyu diturunkan, asbāb al-nuzul, yang tidak

\footnotetext{
${ }^{11}$ M. Arkoun, Kajian Kontemporer al-Qur'an..., h. 48.
} 
semuanya diriwayatkan secara benar) menuju "Korpus Resmi Tertutup" kemudian menuju "Korpus Penafsiran", yakni sejumlah komentar yang ditulis oleh para komentator (penafsir). Para penafsir ini berusaha untuk menjelaskan kebenaran-kebenaran wahyu untuk mencerahi perilaku umat manusia melalui jalur sejarah duniawi di dunia, untuk kemudian sepenuhnya berorientasi menuju dunia lain, yakni akhirat.

Melalui proses panjang sedemikian rupa, korpus edisi dunia memperoleh rasionalisasi kesakralannya melalui konsensus Muslim ortodoks tentang wahyu. Dengan itu, bagi Arkoun, karya-karya interpretatif, seperti karya al-Ṭabari, akhirnya bisa diidentifikasi sebagai kandungan mușhāf seutuhnya. Pandangan masyarakat awam terkait skema di atas benar-benar menyatu. ${ }^{12}$ Bagaimana bisa kalam yang absolut bisa menyatu dengan argumen interpretatif.

Memang sulit menjelaskan kandungan al-Qur'an. Setiap orang beresiko jatuh ke dalam korpus interpretatif. Apalagi urutan surat-surat dan ayat-ayat dalam mușhāf tidak merefleksikan kriteria kronologis, rasional, atau formal, melainkan berdasarkan kriteria apologis atau ijtihadi. Oleh karenanya, penafsiran melalui pendekatan linguistik-semiotik yang hanya terpaku pada keseluruhan isi teks mușhäf memiliki sisi kelemahan historis. Untuk itu, perlu kajian lintas tekstual (intertekstual) dan studi metodologis yang dicurahkan tidak hanya kepada masing-masing korpus secara keseluruhan, tetapi juga terhadap korpuskorpus (kitab suci) lain, yang juga diartikulasikan dengan alat-alat linguistik dan semiotik yang sama dan menggunakan pengetahuan mistis yang sama untuk melahirkan wacana aksiologis yang disebut wahyu. ${ }^{13}$ Dengan langkah ini, setidaknya mampu mengatasi problem linguistik yang terbatas dengan mengkonfirmasikan pada korpus penyedia wacana sebelum al-Qur'an, sekaligus memporoleh sisi historisitas teks, mulai dari al-Qur'an sendiri hingga ke teksteks sebelumnya.

Selain itu, disadari atau tidak, penafsir klasik memberikan pemaknaan dan penafsiran terhadap ayat al-Qur'an berdasarkan pada pemikiran, kebudayaan, dan kebutuhan ideologis yang sesuai dengan zaman, lingkungan sosial, dan avilisasi politiknya. Karena itu, karya tafsir bersifat mitologis, bukan historis. Bahkan hingga saat ini, tafsir model ini masih berlanjut. Ini adalah dampak dari

12M. Arkoun, Rethinking Islam..., h. 60.

13Ibid., h. 63. 
pengaruh politik, pencarian identitas diri (nasionalisme) dan biasanya dilakukan untuk tujuan ekonomi, politik, dan budaya. Untuk itu, Arkoun menilai bahwa penafsiran model ini hanya akan membuat agama sebagai penopang ideologi bagi para pemimpin, tempat persembunyian bagi para oposan, suaka moral bagi kaum tertindas, dan instrument promosi bagi calon pemimpin masyarakat.

\section{Tafsir Dekonstruktif-Historis Mohammed Arkoun}

Sebagai seorang kritikus yang berinteraksi dengan fenomena wahyu, Arkoun berusaha membongkar konsepsionis teks dan istilah-istilahnya guna menyingkap kaidah-kaidah kebangkitan dan mekanisme pergulatannya, sebagai sebuah teks yang mempunyai struktur mitos, efektivitas simbol, dan kekuatan menjelaskan yang estetis, lebih-lebih eksistensi ontologisnya yang menggerakkan kehidupan dan segala hal yang ada. Sebagai kritikus Muslim dan logos Qur'ani, ia sama sekali tidak bersikap seperti sikap orang-orang yang takjub terhadap fenomena wahyu dan keajaiban penurunannya. Arkoun justru menggali dan membongkar, lalu menyingkap apa yang terhalang, memperbincangkan apa yang tidak dibicarakan, dan membaca al-Qur'an melalui historisitasnya, dengan menggunakan alat analisis dan metode kritik terbaru. Pembacaan seperti ini lebih baik ketimbang pembacaan ideologis yang hanya menjadikan pengetahuan mati, yakni pengetahuan final, sehingga tidak ada hal baru yang dapat disumbangkan bagi pemikiran dan pengetahuan.

Arkoun memulai pembacaan kritisnya terhadap problematika sejarah dan penafsiran (hermeneutics). Arkoun berusaha menginvestigasi teks-teks klasik dan membedahnya (dekonstruksi) untuk mencari makna baru yang tersembunyi didalam teks atau mencari teks laten sebagai langkah kontekstualisasi. Perhatian Arkoun tidak hanya tertuju pada teks-teks klasik karya sarjana Muslim, tetapi juga berusaha untuk meneliti asal-usul kesucian teks-teks agama seperti al-Qur'an. ${ }^{14}$ Arkoun menganggap strategi dekonstruksi merupakan strategi terbaik karena akan mengkritisi dan menelanjangi sumber-sumber Muslim tradisional yang mensucikan "kitab suci". Strategi ini berawal dari asumsinya bahwa sejarah al-Qur'an sehingga bisa menjadi kitab suci dan otentik, bahkan menjadi korpus resmi tertutup perlu dilacak kembali. Arkoun

\footnotetext{
${ }^{14}$ Siti Rohmah Soekarba, "The Critique Of Arab Thought: Mohammed Arkoun's Deconstruction Method," dalam Makara, Sosial Humaniora, Vol. 10, No. 2, Desember 2006, h. 81.
} 
mengklaim bahwa strateginya itu merupakan sebuah ijtihad. Ia menyadari bahwa pendekatannya ini akan menantang segala bentuk penafsiran ulama terdahulu, namun ia justru percaya bahwa pendekatan tersebut akan memberikan akibat yang baik terhadap al-Qur'an. Pendekatan ini akan memperkaya sejarah pemikiran dan memberikan sebuah pemahaman yang lebih baik tentang al-Qur'an, dengan alasan karena metode ini akan mengkritisi kembali konsep al-Qur'an yang selama ini telah ada.

Arkoun memandang adanya satu kebutuhan akut atas metode kritik untuk membaca pemikiran Arab atau Muslim yang text oriented. Ia mencoba mengkaji permasalahan-permasalahan tersebut secara konstektual sesuai dengan situasi kontemporer saat ini. Ia mengacu pada ilmu-ilmu sosial, bahasa, dan filsafat yang berkembang saat ini. Sebagai contoh dia banyak menggunakan teori-teori antropologi, sejarah dan sosiologi, karena menurutnya disiplin ilmu-ilmu ini sangat penting bagi umat Islam. ${ }^{15}$ Melalui pelbagai pendekatan ini Arkoun berharap dapat memahami dan membandingkan antara celah-celah kenyataan dan cita-cita ideal umat Islam, dan akhirnya dapat menjembatani kesenjangan tersebut. ${ }^{16}$ Oleh sebab itu, konsen Arkoun ini dikenal sebagai "Kritik Nalar Islam".

Kritik yang dilontarkan Arkoun erat katannya dengan sistem sosial budaya masyarakat, di mana Arab dianggap sebagai representasi dari Muslim. Semua hasil semiotik masyarakat dalam proses penampakan sejarah dan budaya merupakan sasaran dari perubahan sosial yang disebut oleh Arkoun sebagai historicity. Teks al-Qur'an, sebagai artikulasi makna bagi alat sosial dan budaya, juga merupakan sasaran dari historicity. ${ }^{17}$ Karena itu Arkoun memperlakukan al-Qur'an sebagai produk sejarah yang pantas dikaji dengan pendekatan sejarah.

"pendekatan historisitas, sekalipun berasal dari Barat, namun tidak hanya sesuai untuk warisan budaya Barat saja. Pendekatan tersebut dapat diterapkan pada semua sejarah umat manusia dan bahkan tidak ada jalan lain dalam menafsirkan wahyu kecuali menghubungkannya dengan konteks historis". h. 267.

${ }^{15}$ M. Arkoun, Ma ârik min Ajli al-Ansanah fi al-Siyaqat al-Islämiyyah (Beirut; Dar Al-Saqi, 2001),

16Baidhowi, Antropologi al-Qur'an (Yogyakarta: LKIS, 2009), h. 18.

${ }^{17}$ Ali Harb, Kritik Nalar al-Qur'an (Yogyakarta: LKiS, 2003), h. 96. 
Arkoun juga menyatakan bahwa Strategi terbaik untuk memahami historisitas keberadaan umat manusia ialah dengan melepaskan pengaruh idiologis, kemudian beranjak menggunakan metodologi multidisipliner dari ilmu sejarah, sosiologi, antropologis, psikologis, bahasa, maupun semiotik untuk mempelajari sejarah dan kebudayaan Islam. Jika strategi ini digunakan, maka umat Islam bukan saja akan memahami secara lebih jelas masa lalu dan keadaan mereka saat ini untuk kesuksesan mereka di masa yang akan datang, namun juga akan menyumbang kepada ilmu pengetahuan modern.

Dengan historisitasnya, Arkoun sebenarnya meminjam teori hermeneutika dari Paul Ricour dalam penafsiran al-Qur'an, sehingga ia memperkenalkan tiga level wahyu; Pertama, wahyu sebagai firman Allah yang tak terbatas dan tidak diketahui oleh manusia, yaitu wahyu al-Lauh al-Mahfüdz dan Umm al-Kitāb. Kedua, wahyu dalam lintasan sejarah diskursus kenabian, dan ketiga, wahyu sebagaimana tertulis dalam mușhāf dengan huruf dan berbagai macam tanda yang ada di dalamnya. Ini menunjuk pada al-Mușhāf al-Uthmānī yang dipakai orang-orang Islam hingga hari ini. Dari ketiga level itu, hanya level kedua dan ketiga lah yang bisa diakses dan dikaji oleh pembaca yang berkepentingan dengan al-Qur'an.

Meskipun demikian, Arkoun menghimbau para pembaca untuk mengkaji al-Qur'an menurut kaidah-kaidah metode yang dapat diterapkan pada setiap naskah agung doktrinal dan mapan:

1. Membebaskan makna dari sacra doctrina dalam Islam dengan menundukkan naskah Qur'ani dan semua naskah dalam sejarah pemikiran Islam, yang telah berusaha menjelaskan pada suatu ujian kritis diri dalam rangka menghilangkan kerancuan-kerancuan, kekeliruan, penyimpangan dan kekurangan serta mengarahkannya pada ajaran-ajaran yang tetap benar dan berlaku;

2. Merumuskan kriteriologi yang akan dianalisis dan dikemukakan oleh intelegensi kontemporer, baik untuk menolak maupun untuk mempertahankan konsepsi-konsepsi yang dipelajari.18

Selanjutnya, untuk mewujudkan keberagaman makna, Arkoun berusaha menghadirkan langkah-langkah pengkajian al-Qur'an ke dalam tiga momentum:

${ }^{18}$ M. Arkoun, Kajian Kontemporer al-Qur'an..., h 48. 
1. Momentum linguistik yang memungkinkan kita untuk menemukan keteraturan dasar di bawah keteraturan bahasa yang tampak,

2. Momentum antropologis yang akan konsisten untuk mengenali kembali bahasa struktur mitis dalam al-Qur'an, dan

3. Momentum historis yang di dalamnya akan ditetapkan jangkauan dan batasbatas tafsir logika-leksikografis dan tafsir-tafsir imajinatif yang sampai hari ini masih dicoba oleh kaum Muslim. ${ }^{19}$

Melalui tawaran-tawaran tersebut, apa yang dilakukan oleh Arkoun merupakan sumbangan untuk membendung upaya politisasi tafsir al-Qur'an yang dilakukan oleh orang-orang berkepentingan.

\section{Tafsir Politik Mohammed Arkoun}

Bagaimana timbulnya kaitan-kaitan antara agama dan politik (negara) menurut al-Qur'an dan tindakan Nabi? Karena semua kekuasaan politik yang muncul di bumi Islam sejak tahun 632 telah menyatakan diri berlandaskan ajaran-ajaran al-Qur'an dan Nabi serta mengemban tugas mulia sebagai penjaga ajaran-ajaran tersebut, maka terbentuklah suatu visi imperial sesuai dengan Islam sebagai agama (al-dīn), negara (al-dawlah), dan dunia sekuler (al-dunyā) yang tak terpisahkan. Khazanah ilmiah modern telah menggambarkan hubungan itu dengan mengulang-ulang bahwa Islam sejak awal memang sudah memadukan antara yang abadi dan yang sementara, antara yang sakral dan yang profan.

Sebelumnya, perlu diketahui bahwa penyusunan Korpus Resmi dari berbagai ujaran resmi wacana qư'ani menjadi naskah, masih dipahami sebagai kalam yang mungkin bersifat propetik, naratif, legislatif, hikmah dan himnis sehingga mampu mendorong suatu perbuatan dan gerakan. Arkoun memulai dengan mengajukan contoh dalam QS. al-Syu'ara: 105-120:

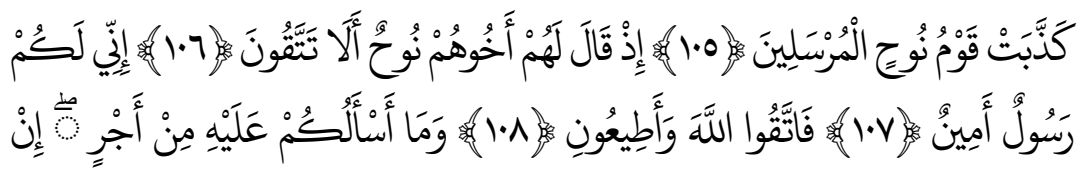

19 Ibid., h. 49. 


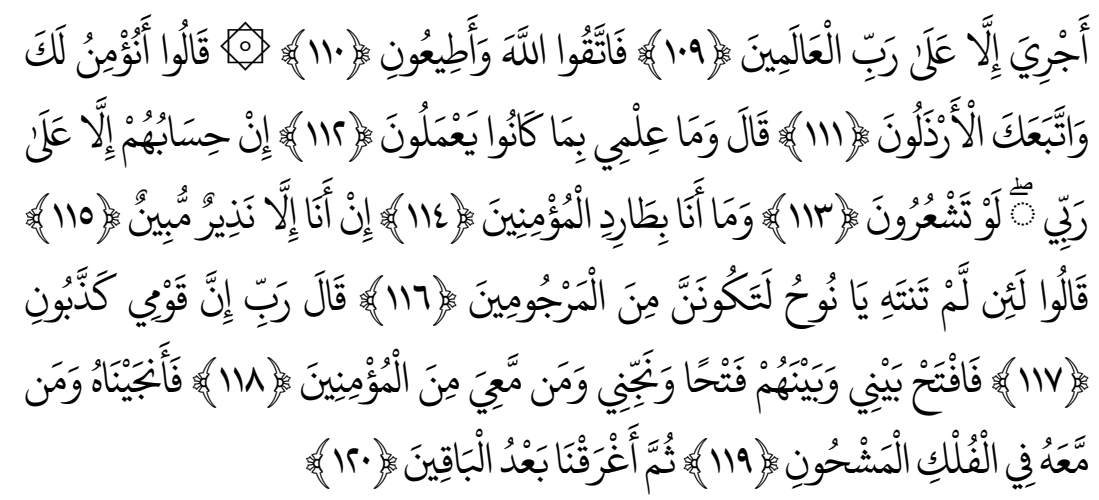

Ketokohan Nuh dalam rangka mengajak umatnya untuk mengikutinya selalu dihadapkan pada ketakwaan pada Allah. Dengan surat yang sama, Arkoun menemukan pola riwayat kenabian lain yang hampir mirip atau sama dengan pola riwayat Nuh, terdiri dari lima Nabi awal, yaitu Nuh, Hud Shalih, Luth, dan Syu'aib. Semuanya menyampaikan seruan kepada kaumnya dengan ujaranujaran yang hampir sama, serta terjadi pengulangan terus-menerus; bertakwalah kepada Allah dan ta'atlah kepadaku, untuk kemudian mengarahkan pada konsep keselamatan yang diperoleh oleh umat-umat terdahulu. ${ }^{20}$ Pengkajian historisitas tampaknya hanya diarahkan untuk mengamati penggalanpenggalan yang terulang dalam surat itu dan penyebarannya pada masyarakat saat itu, 'Ad dan Tsamud. Dari kelima kisah tersebut, dihadirkan kembali sekaligus untuk mengungkapkan situasi Muhammad yang sedang kualahan menghadapi para oposan Makkah dengan menghubungkan situasi tersebut pada aturan yang dipandu Tuhan dalam sejarah keselamatan ciptan-ciptaan. Inilah salah satu watak wacana qur'ani, yaitu dengan meminta bantuan teladanteladan kuno (amthāl) untuk memodifikasi suatu sosio-politik saat itu.

Dari kelima contoh dalam QS. al-Syu'ara menunjukkan adanya struktur aktansial dalam wacana Qur'ani. Dari sudut pandang sintaksis, semantik dan semiotik, wacana tersebut didominasi oleh aktan Tuhan yang dinyatakan secara berandang (Tuhanku, Kami, ...) ataupun secara tersirat (seorang Rasul, seorang pemberi peringatan, ...). Aktan pertama ini secara serentak adalah penuturpengarang, pengirim dan penerima dibandingkan dengan kedua aktan lainnya. Para Rasul adalah aktan-aktan perantara, dan kemudian disebut aktan kedua. Mereka adalah pengujar kalam yang disampaikan pada mereka. Pada seruan

${ }^{20}$ Lihat diksi periwayatannya dalam QS. al-Syu'ara ayat 105-120 . 
untuk ketaatan pada Allah dan aku (Rasul) menunjukkan konsekuensi dan salah satu manifestasi ketaatan wajib kepada Allah. Dalam surat-surat Madaniyah, alQur'an membela dengan tujuan yang sama agar Muhammad dita'ati. Formula taatilah Allah dan Rasul terulang sebanyak 29 kali. Sementara kaitan ketaatan antara sesama manusia atau antara manusia dan Allah dengan perantara Nabi diungkapkan dalam 73 redaksi yang berakar dari kata to $a^{\prime} a(\text { taat })^{21}$

Selain itu, terdapat aktan ketiga (manusia, orang-orang atau kelompok, termasuk para penolong Nabi) menunjukkan suatu oposisi utama dari seluruh wacana Qur'ani dihadapan berbagai perintah atau larangan dari aktan penuturpengarang-pengirim, dalam konteks ini merujuk pada para penolong (anshar) yang disebut oleh al-Qur'an sebagai mu'minūn atau Muslimūn, dan di sisi lain memunculkan oposan yang disebut kāfirūn. perpecahan fundamental ini terungkap melalui struktur biner yang luas dari semua leksikon Qur'ani. ${ }^{22}$ Pembedaan keduanya adalah bentuk sublimasi keagamaan dari suatu ketegangan sosio-politik antara mereka yang tunduk pada kekuasaan baru (kekuasaan Muhammad) dan mereka yang menentangnya. Sementara itu, kedua bentuk oposisi biner masing-masing memiliki turunan-turunan yang mengarah ke hitam-putih, salah-benar. ${ }^{23}$

Apabila kita menela'ah wacana teologis dan historiografis, klaim-klaim tersebut muncul sebagai respon upaya pendudukan Negara umat di Madinah atas Makkah. Wacana qur'ani era awal merupakan wacana performatif, bukan sebagai wacana naskah belaka. Penyebutan kāfirūn (orang-orang kafir) yang menimbulkan konsepsi teologis vis a vis dengan mu'minūn (orang beriman) atau Muslimūn (orang Islam) pada awalnya diterapkan pada penduduk Makkah yang secara politik menentang agama baru, sementara Muslimūn adalah kekuatan politik baru yang kemudian dimantapkan di Madinah. Kenyataan ini bisa dibuktikan dalam 'konstitusi Madinah'. Di dalamnya digambarkan bagaimana Muhammad saw. memperluas pengikut politiknya dengan mengadakan aliansi-

\footnotetext{
${ }^{21}$ M. Arkoun, Kajian Kontemporer al-Qur'an..., h 225.

22 Ibid. Lihat juga Toshihiko Izutsu, Ethico-Religious Concept in the Qur'an, Montreal, 1996.

${ }^{23}$ Kita bias melihat turunan-turunan dari berbagai akar kata khshy sebanyak 47 kali, khauf (takut) sebanyak 62 kali, wqy (takut lagi penuh bakti) sebanyak 229, dan aslama (bersedia bergabung dengan kelompok yang direkadaya oleh norma-norma qur'ani dan tindakan politik Nabi). Sementara dalam pihak oposisi: 'āshy (menentang) sebanyak 32 kali, 'adw (musuh/melanggar batas) sebanyak 99 kali, thäghy> (sewenang-wenang) sebanyak 39 kali, Fir'aun (simbol pemimpin penganiaya, penindas dan penentang) sebanyak 74 kali, baghā (hasrat untuk melanggar) sebanyak 96 kali, khatha' (salah) sebanyak 22 kali, itsm (dosa) sebanyak 48 kali, dan junnah (keluhan) sebanyak 32 kali. M. Arkoun, Kajian Kontemporer al-Qur'an..., h. 227.
} 
aliansi bersama suku-suku setempat, yaitu Yahudi dan Arab. Mereka yang masuk aliansi merupakan satu konfiderasi (ummat, dengan makna tribal yang kemudian berevolusi berkat wacana qur'ani, menuju konsepsi komunitas spiritual transhistoris) yang anggotanya harus saling melindungi dengan jaminan suatu ketentraman (aman).

Ketaatan maupun penentangan merupakan suatu pertaruhan langsung yang ditonjolkan melalui janji atau ancaman dari kehidupan yang abadi. Lawan politik diklaim sebagai kafir dengan ancaman neraka, sementara pembela disebut sebagai mukmin dengan janji surga. Pertaruhan itu sebenarnya bentuk perlindungan dan pengukuhan konfiderasi di Madinah -antara Anshar dan pribumi- untuk menundukkan Makkah. Penaklukan Makkah ini secara mutlak diputuskan, tidak hanya untuk mereduksi oligarki yang mencekam, tatapi terutama untuk memantapkan suatu dasar teritorial sakral supaya tidak terpaku pada landasan politik yang rapuh di Madinah. Di samping itu, wacana qur'ani terkait baitullah yang dimiliki oleh sejak Nabi-nabi terdahulu dihadirkan pula untuk memperkuat argumentasi bahwa Makkah sebenarnya memiliki keterkaitan dengan misi Muhammad.

Begitulah suatu agenda politik yang dibalut dengan wacana teologis, sehingga mampu mengubah sejarah yang profane menjadi kisah sakral dengan kekuasaan sakralisasi yang besar. Untuk itu, perlu menela'ah kembali ayat-ayat yang telah menggiring pada agenda politik Nabi Muhammad dengan segala bentuk strategi juga peperangan-peperangan terencana untuk menaklukkan Makkah. Di mana identitas Muslim dan Kafir mulai ditafsirkan dan disematkan untuk mengamputasi gerak pihak oposan yang menentang penguasa. Hingga saat ini masih banyak pihak berkepentingan yang membawa ayat-ayat semacam ini untuk menyudutkan lawan politiknya dengan klaim-klaim spekulatif. Di sinilah agama dibawa ke dalam politik.

\section{E, Utopia Khilafah Islāmiyah dan Konsep Negara Ideal Mohammed Arkoun}

Dalam membicarakan relasi antara agama dan Negara, dalam tulisan berjudul "Madkhāl li Dirāsah al-Rawābit bayna al-Islām wa '-Siyāsah" dalam bukunya al-Fikr al-Islami, Qirā'ah 'Ilmiyyah, Arkoun berpendapat bahwa relasi Islam dan politik dapat didekati melalui dua pendekatan. Pertama, pendekatan historis yang konvensional yang bersifat deskriptif. Kedua, pendekatan pemikiran dan perenungan kembali tentang berbagai problematika dan kesulitan yang pernah 
muncul berkaitan dengan Islam dan politik, dimulai sejak pengalaman misi kenabian Muhammad di Mekah, maupun pengalaman politisnya di Madinah. ${ }^{24}$

Sementara dalam tulisan lain, al-Islām al-Akhlāq wa 'l-Siyāsah, Arkoun menyatakan teori tentang Daulah Islamiyah sebenarnya sangat variatif. Umumnya umat Islam berkeyakinan bahwa setiap Muslim berkewajiban untuk mentaati segala perintah Allah tanpa reserve. Setiap komunitas Muslim wajib mentaati aturan Allah sekaligus hukum yang dibawa oleh Nabi Muhammad. ${ }^{25}$ Secara normatif-historis, al-Qur'an menuturkan bahwa manusia pertama Adam as diturunkan Tuhan ke bumi berfungsi sebagai khalifah yang melebihi kedudukan setan bahkan malaikat sekalipun. Walaupun dalam realitas historisnya Adam sang khalifah pernah tergoda, karena kelemahan manusia, oleh godaan setan, namun akhirnya Adam kembali bertobat dan tunduk dengan syariat Ilahiah yang sebenarnya. Inilah daulah pertama dalam sejarah kemanusiaan yang terekam dalam al-Qur'an. Kedaulatan ilahiah ini terus berlanjut pada masa para Nabi berikutnya sesudah Adam, terutama Nuh, Musa, Ibrahim, Dawud, Sulaiman, Isa hingga Muhammad. Jadi semua Nabi, demikian keyakinan mayoritas Muslim, telah membangun apa yang disebut dengan daulah ilahiah yang berdasarkan syari'at Islam. ${ }^{26}$

Dalam sejarah pemikiran politik dan etika Islam ternyata tak dapat dinafikan munculnya tentang teori daulah Islamiah (Islamic state/religion state) sebagai ideologi politik. Hal ini disebabkan kebanyakan negara-negara Muslim terutama di Arab- pernah mengalami berbagai benturan keras akibat penjajahan asing. Faktor inilah yang membuat umat Islam menjadikan agama sebagai icon perjuangan ideologi politik. ${ }^{27}$ Keterkaitan antara agama dan negara secara historis sangat bervariasi, sehingga menimbulkan pluralitas pemikiran politik. Masalah khilāfah termasuk wilayah yang diperdebatkan di kalangan Muslim (khilafiyah). ${ }^{28}$ Bagi Arkoun, khiläfah merupakan sebuah gagasan yang

${ }^{24}$ Mohammed Arkoun, al-Fikr al-Islāmy, Naqd wa Ijtihād, terj. Hasyim Shalih (Beirut: Dar alSaqi, 1992), h. 143.

25Ibid., h. 203-205.

26Muhammad Azhar, "Relasi Agama dan Negara Dalam Perspektif Mohammed Arkoun," dalam Hermenia - Jurnal Kajian Islam Interdisipliner, PPs UIN Sunan Kalijaga, Vol. 6, No. 1, JanuariJuni 2007, h. 186-187.

${ }^{27}$ Ibid., h. 186.

${ }^{28}$ Arkoun mengemukakan fakta pluralitas pemikiran politik: pertama, adanya ketidaktundukan Muawiyah pada rezim syariat, karena merasa kelompok Muawiyah bukanlah termasuk bahagian dari keluarga dekat Rasulullah saw. Kedua, secara faktual Nabi saw. sendiri tidak memiliki putra 
sangat utopis. Arkoun berargumen bahwa isu khiläfah ini tidak ada kesepakatan di kalangan umat, karena berbeda penafsiran teks agama serta latar belakang sosial budaya masing-masing negara Muslim. Selain itu, intervensi negara dalam wilayah keagamaan akan berdampak pada manipulasi simbol-simbol keagamaan dan akan mereduksi kebebasan beragama dan berpolitik masyarakat. Bahkan berpeluang terjadinya kolusi antara penguasa dan otoritas keagamaan. Oleh sebab itu, otoritas keagamaan dan politik kenegaraan harus dibedakan, tetapi tetap berhubungan.

Intervensi kekuasaan negara terhadap suatu agama secara berlebih rentan menimbulkan disintegrasi bangsa. Diskriminasi terhadap agama minoritas, munculnya hegemoni Negara atas agama, bahkan munculnya penggunaan agama sebagai alat dan komoditas politik. Penundukan agama oleh negara justru akan menimbulkan penindasan, baik terhadap kebebasan beragama maupun kebebasan berpolitik. Negara perlu membiarkan eksistensi agama, karena agama adalah urusan pribadi penganutnya dalam hubungannya dengan Tuhan, sementara negara sama sekali tidak berhak untuk mencampuri urusan tersebut. Masing-masing memiliki wilayah otonomi. Meskipun demikian, masing-masing agama maupun negara tetap mempunyai tanggungjawab terhadap satu sama lainnya. Kehidupan manusia sebagai insan Tuhan diatur agama, dan manusia sebagai unsur masyarakat juga diatur negara.

Dalam menjalankan tugasnya, negara yang menerapkan syari'at agama haruslah bersifat inklusif, bukan eksklusif, serta bertumpu pada eksplorasi nilainilai keagamaan yang universal melalui jalur-jalur yang demokratis. Langkah tersebut untuk memberikan kebebasan kepada penganut agama tanpa dibayangi ketakutan secara ekstrim-eksklusif dan fundamentalistik, sehingga bisa diterima. Bentuk kenegaraan seperti ini bisa disebut dengan religious state (bukan religion state) serta merupakan jalan tengah yang dapat meredam ketegangan ideologis-politis yang berkepanjangan di berbagai Negara Muslim. ${ }^{29}$

Dalam sejarahnya, pernah terjadi perbedaan dalam penetapan syari'at yang dilakukan sahabat dengan apa yang sudah ditetapkan oleh Nabi sebelumnya. Misalnya, ketika Abdurrahman bin Auf memutuskan untuk memisahkan kota

pewaris dan penerus kepemimpinannya. Ketiga, pewaris Nabi -para khalifah Islam- tidak lagi mendapatkan wahyu sebagaimana yang diterima oleh beliau. Ibid., h. 187.

${ }^{29}$ Ibid., h. 190. 
Madinah, dimana dia meminta pendapat dari para ahli pikir tentang seseorang yang laik menjadi khalifah pasca Umar bin Khattab. Dia tidak mendelegasikan Usman sebagai khalifah melainkan setelah adanya konsensus dari orang-orang dekatnya. Kasus inilah yang menururut Arkoun dinyatakan sebagai konsep shūrā yang sebenarnya identik dengan demokrasi. Dengan sistem syurā atau demokrasi ini, penerapan syariat Islam lebih bersifat rasional-diskursif dan substantif, dari pada tekstual-normatif. Sistem ini bisa diterima sepanjang bisa mengakomodasi nilai-nilai universal dari ajaran Islam. Karenanya, sangat wajar bila Arkoun menyatakan bahwa ide Islamic State merupakan pandangan yang sangat utopis. Apa yang dilakukan Khomeini dalam menciptakan sebuah Islamic State, pada dasarnya tidak bisa menyelesaikan persoalan teologis antara Islam Syiah dan Sunni. Karena itu, Khomeini hanya menciptakan sebuah negara nasionalis Iran, bukan sebuah negara Islam. Sehingga dampak yang terjadi di Iran sekarang ini adalah semua menuntut iklim yang lebih demokratis. Dari itu, perlu mengelaborasi teori modern dalam pemikiran politik. Demikian lah yang digagas Arkoun dengan pemikiran kembali terhadap Islam.

\section{F. Kesimpulan}

Gagasan Arkoun terkait dekonstruksi dan historitas sebagai pendekatan studi al-Qur'an telah menciptakan paradigma baru tentang hakikat teks alQur'an. Arkoun hendak mendekonstruksi kemapanan tafsir yang telah sekian lama berjalan tanpa kritik nalar yang berarti, dengan mendorong untuk mengembalikan al-Qur'an pada wacana Qur'ani yang sangat terbuka terhadap setiap pemaknaan. Meskipun demikian, gagasan historisitas Arkoun justru menggiringnya untuk menyimpulkan sesuatu yang ahistoris, yaitu kesakralan dan kebenaran wahyu hanya ada pada level di luar jangkauan manusia. Arkoun tetap mengakui kebenaran dan kredibilitas bentuk lisan al-Qur'an, tetapi bentuk itu sudah hilang selama-lamanya dan tidak mungkin ditemukan kembali karena sudah terbakukan dalam bentuk Korpus Resmi tertutup (al-Mușhāfal-Uthmānī). Baginya kebenaran Umm al-Kitāb hanya ada pada Allah sendiri, dan apa yang diperdebatkan umat Islam tentang al-Qur'an merupakan perdebatan atas penafsiran al-Muṣhāf al-Uthmānī yang merupakan ijtihādiyyah umat Islam masa awal.

Kaitannya dengan relasi agama dan negara memang tidak ada kesepakatan di antara umat Islam atas bentuk ideal negara dalam Islam. Ketidaksepakatan ini 
tentunya memiliki beragam argumentasi yang didasarkan pada interpretasi alQur'an. Namun demikian, tampaknya konsep tentang Khiläfah Islamiyah atau Islamic State dipaksakan oleh kelompok Islamis untuk tujuan politik tertentu. Arkoun menganggap usaha ini bukan murni warisan ajaran Nabi, melainkan muncul dari persepsi atas firman Allah. Mereka kehilangan konteks historis yang secara 'sadar' menunjukkan adanya ketegangan politik yang terjadi antara kelompok Nabi Muhammad saw. dan kelompok penentangnya. Klaim-klam identitas kafir atau Muslim dihadirkan untuk menciptakan pembeda yang tajam antara kelompok militan dan oposan. Konsep kafir-Muslim yang sebenarnya muncul akibat konteks sosio-politis dirubah sedemikian rupa, atau setidaknya dipahami sebagai konsep teologis dengan segala konsekuensinya, yakni ancaman dan janji yang abadi. Dengan adanya perubahan status menjadi teologis, agama telah dibawa untuk melancarkan kekuatan politik. Agama tidak lagi menjadi sebuah keyakinan, melainkan sebagai ideologi politik untuk mewujudkan Islamic State. Dengan demikian, menunjukkan bahwa agama memiliki kekuatan dalam membentuk sebuah peradaban manusia.[]

\section{DAFTAR PUSTAKA}

Arkoun, Mohammed, Kajian Kontemporer al-Qur'an, diterjemahkan dari buku Lectures du Coran, terj. Hidayatullah, Bandung: Pustaka, 1998.

Rethinking Islam, terj. Yudian W. Asmin, Yogyakarta: Pustaka Pelajar, 1996.

al-Fikr al-Islāmy, Naqd wa Ijtihād, terj. Hasyim Shalih, Beirut: Dar al-Saqi, 1992.

- Ma'arik min Ajli al-Ansanah fi al-Siyaqat al-Islamiyyah, Beirut: Dār al-Saqi, 2001.

Tārikhiyah al-Fikr al-'Arabiy al-Islāmī, terj. Hasyim Shalih, Beirut: Markaz al-Inma' al-Qoumi, 1986.

Azhar, Muhammad, "Relasi Agama dan Negara dalam Perspektif Mohammed Arkoun", dalam Hermenia - Jurnal Kajian Islam Interdisipliner, PPs UIN Sunan Kalijaga, Vol. 6, No. 1, Januari-Juni 2007.

Baidhowi, Antropologi al-Qur'an, Yogyakarta: LKIS, 2009. 
el-Fadl, Khaled Abou, Atas Nama Tuhan: Dari Fikih Otoriter ke Fikih Otoritatif, diterjemahkan dari Speaking in God's Name: Islamic Law, Authority and Women, Jakarta: Serambi, 2003.

Harb, Ali, Kritik Nalar al-Qur'an, Yogyakarta: LKiS, 2003.

http://www.filsafatpemikiranmuhammadarkoun.com.

Salihu, Abdul Kadir Hussain, Hermeneutika al-Qur'an menurut Muhammad Arkoun: Sebuah Kritik, dalam ISLAMIA: Majalah Pemikiran Dan Peradaban Islam, Tahun I No 2, Juni-Agustus 2004.

Soekarba, Siti Rohmah, The Critique Of Arab Thought: Mohammed Arkoun's Deconstruction Method, dalam Makara, Sosial Humaniora, Vol. 10,No. 2, Desember 2006.

Toshihiko Izutsu, Ethico-Religious Concept in the Qur'an, Montreal, 1996.

Wahid, Abdurrahman (ed), Ilusi Negara Islam: Ekspansi Gerakan Islam Transnasional di Indonesia, Jakarta: The Wahid Institute, 2009. 
